\title{
THE CATEGORIES OF SPECIALIZED VOCABULARY IN THE SPHERE OF AUTOMATION TO DEVELOP STUDENTS' FOREIGN LANGUAGE COMMUNICATIVE SKILLS
}

\section{Yakushko K. H.}

\section{INTRODUCTION}

The problem of linguistic studies support on the practical lessons of professionally oriented foreign language for Ukrainian future technicians has been attracting attention of researches for a long time ${ }^{1}$. Nowadays it is important to modernize the process of foreign language studying as the initial acquaintance with the background of specialty in general and with English for communication itself. ${ }^{2}$

Automation is an important branch of technical science with its rapid development as well as computer-aided technologies or robotics. That is why it is in need to elaborate adequate foreign language manuals according to such sciences. Our goal was to broaden the understanding of the concept "Future Specialist in Automation" to interpretate it as one who is profoundly involved into the interdisciplinary aspect either of technical or of linguistic knowledge. It will improve technical students' foreign language knowledge as well as to transform it into students' professional soft skills.

Thus it is necessary to define some general theoretical principles to determine the categories of professional vocabulary being involved into studying on the professionally oriented foreign language lessons as well as to determine the results of these theoretical principles practical application exampling experience with 112 future specialists in automation within the Research and Educational Institute of Energetics, Automation and Energy Efficiency being belonged to the National University of Life and Environmental Sciences of Ukraine. The experiment lasted during the first semester of 2019/2020 studying period.

Якушко К.Г. Педагогічні умови формування професійно орієнтованого іншомовного спілкування у студентів технічних спеціальностей аграрних університетів: монографія. / за наук. ред. проф. Л.О. Калмикової. Київ : Компринт, 2017. 244 c.

${ }^{2}$ Liudmyla V. Berezova, Svitlana V. Mudra, Kateryna H. Yakushko. The Effect of Webquests of the Writing and Reading Performance of University students. Information Technologies and Learning Tools. 2018. Vol. 64, No. 2. P. 110-118. 


\section{Basic theoretical principles to determine the categories of a professional vocabulary being involved into studying on the professionally oriented foreign language lessons}

There are several approaches to subdivide lexical units in order to develop foreign language speech for non-linguistic specialization students . In our case the main theoretical principles to determine the categories of professional vocabulary being involved into studying on the professionally oriented English language lessons may be based on their functional purpose.

First of all, we'd like to divide the work with specialized vocabulary for the development of foreign language students in every sphere of knowledge into six categories:

1) 1S: professionalvocabulary as some abbreviations being corresponded with common words in order to revive technician's interest in linguistic work;

2) $2 \mathrm{~S}$ : professional vocabulary in associative relations with emotional and psychomotor memories;

3) 3S: professional vocabulary being selected by common morpheme for adaptation to accept foreign terms by nesting method;

4) $4 \mathrm{~S}$ : professional vocabulary being selected by frequency of use in professional adapted foreign-language texts and by the most distinguished structural features;

5) $5 \mathrm{~S}$ : professional $1 \mathrm{~S}, 2 \mathrm{~S}, 3 \mathrm{~S}, 4 \mathrm{~S}$ vocabulary within a shortened list of the most used and the most suitable for professional use term compounds;

6) $6 \mathrm{~S}$ : professional vocabulary as the current review of residual linguistic knowledge.

At first look, we consider each professional term system of a particular branch of knowledge to be unique system and not reproducible one for other sciences. Thus, we are not able to state direct reproduction of the common elements between specialized sciences vocabularies while allowing the possibility of similar terms existance concerning automation, mechanical engineering or power engineering vocabularies. It is only exception for $6 \mathrm{~S}$ (professional vocabulary as the last review of residual linguistic knowledge) being represented in a general table 1 is to be filled up by every student before project work at the end of foreign language studying: 
Current review of residual students' professional vocabulary knowledge

\begin{tabular}{|c|c|c|}
\hline & Task & Student's answer \\
\hline 1 & $\begin{array}{l}\text { Write 5-10 variants of professional } \\
\text { vocabulary as some abbreviations } \\
\text { being corresponded with common } \\
\text { words in order to revive technician's } \\
\text { interest in linguistic work }\end{array}$ & 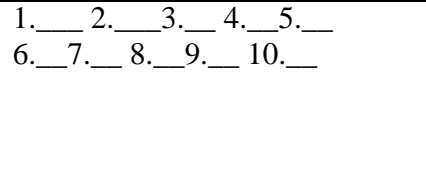 \\
\hline 2 & $\begin{array}{l}\text { Write 5-10 variants of professional } \\
\text { vocabulary in associative relations } \\
\text { with emotional and psychomotor } \\
\text { memories }\end{array}$ & 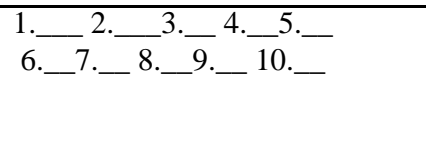 \\
\hline 3 & $\begin{array}{l}\text { Write } 5-10 \text { variants of professional } \\
\text { vocabulary being selected by } \\
\text { common morpheme for adaptation to } \\
\text { accept foreign terms by nesting } \\
\text { method }\end{array}$ & 1. $6{ }^{2} \cdot{ }^{3}{ }^{3} \cdot{ }^{9} \cdot{ }^{4} \cdot \overline{1}^{5} \cdot-$ \\
\hline 4 & $\begin{array}{l}\text { Write } 10-15 \text { variants of professional } \\
\text { vocabulary being selected by } \\
\text { frequency of use in professional } \\
\text { adapted foreign-language texts and } \\
\text { by the most distinguished structural } \\
\text { features }\end{array}$ & 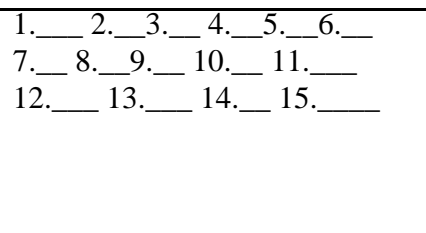 \\
\hline 5 & $\begin{array}{l}\text { Write 30-33 variants of vocabulary } \\
\text { within a shortened list of the most } \\
\text { used and the most suitable for } \\
\text { professional use term compounds }\end{array}$ & 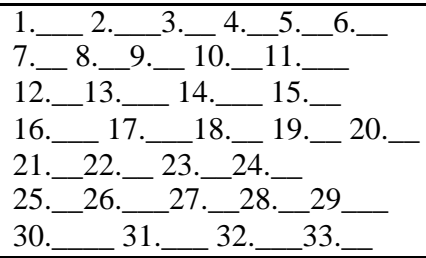 \\
\hline
\end{tabular}

As it is shown, the most detailed elaboration is recommended for p. 4 and p. 5. Such table is to be filled up by every student before project work at the end of foreign language lessons studying.

\section{Practical experience for future specialists in automation to involve professional vocabulary-abbreviations being corresponded with common words, in associative relations with emotional and ps ychomotor memories and being selected by common nesting morpheme}

The description of practical experience for future specialists in automation to involve professional vocabulary-abbreviations being corresponded with common words, professional vocabulary in associative relations with emotional and psychomotor memories and professional 
vocabulary being selected by common nesting morpheme is important part to show the first stages of the pointed theoretical grounds application.

The question of identifying those abbreviations that would simplify the process of mastering specialized foreign language vocabulary is based on the choice of those options, which are similar to the common spread words. In our previous article, we noted five sub-groups of English abbreviations being in similar written form to the common nouns ${ }^{3}$.

To determine similar specific features of such nouns as bones, bus, cap, campus, car, card, cat, care, code, coin, fact, girl, race, ear, lace, lip, lips, rat, mask, map, fun, salt, sea, soap and spice were taken into consideration. These nouns become relative to the sphere of automation if to represent them as some abbreviations. The most spread group is the group to include some abbreviations being homonymous with common nouns with unambiguous (one way) interpretation in such range as BONES (Block-Oriented NEtwork Simulator), BUS (Broadcast and Unknown Server), CAMPUS (Clustered Architecture Massively Parallel Unified - memory System), CODE (Client/Server Open Development Environment), COIN (COmmand Information), LACE (Local Automatic Circuit), LIP (Large Internet Packets), LIPS (Logical Inferences Per Second), MASK (Multilevel Amplitude Shift Keying), SOAP (Symbolic Optimal Assembly Program), SPICE (Simulation Program with Integrated Circuit Emphasis), SEA (Standard Electronic Assembly), EAR (Electronic Audio Recognition) and GIRL (Generalized Information Retrieval Language).

The second group of automation acronyms are homonymic to common nouns with ambiguous (two ways) interpretation. It includes such nouns as CARD (1. CarsAutomated Reproduction and Distribution CarsAutomated Reproduction and Distribution, 2. Computer-Assisted Route Development), CARE (1. Computer-Aided Reliability Estimation, 2. Computer Aided Reusable Engineering), FUN (1. FUNction, 2. Functional Unit Number).

Another group of automatic acronyms being homonymous with common nouns with three-digit (three ways) interpretation. It also has several representatives like RACE (1. Random Access Computer Equipment, 2. Rapid Automatic Checkout Equipment, 3. Regional Automatic Circuit Exchange) and SALT (1. Script Application Language for Telix, 2. Subscriber Automatic Line Test, 3. Symbolic Algebraic Language Translator).

Abbreviation FACT (1. Fingerprint Automatic Classification Technique, 2. Flexible Automatic Circuit Tester, 3. Forecast And Control Technique, 4. Fully Automatic Compiling Technique) and abbreviation RAT(1. Receiver

3 Якушко К.Г., Полішук А.В. Особливості співзвучності загальновживаних іменників 3 абревіатурами технічних термінів. Науковий вісник Національного університету біоресурсів $і$ природокористування Украӥни. Серія "Філологічні науки». 2018. Вип. 292. С. 222-227. 
And Transmitter, 2. Register Alias Table, 3. Remote Access Terminal, 4. Remote Automatic Telemetry Equipment) belong to the group with automation abbreviations being similar to common nouns in four ways interpretation.

The group of abbreviations being related to the sphere of automation are similar to common nouns in writing as multivariate interpretation include such abbreviations as $C A R, M A P$ and $C A P$. Abbreviation $C A R$ has four variants of decoding: 1. CARrier, 2. Central Access Routing, 3. Channel Address Register, 4. Channel Assignment Record, 5. Computer-Assisted Retrieval, 6. Contents of Address Register, 7. Control Unit Accumulator Register, 8. Current Address Register. Abbreviation MAP is distinguished by the possibility of being interpreted in eleven versions: 1. Matrix Associative Processor, 2. Manageability, Availability, Performance, 3. Manufacturing Automation Protocol, 4. Memory Acceptance Pulse, 5. Memory Access Protection, 6. Memory Allocation and Protection Unit, 7. Message Administration Procedures, 8. Microprocessor Analysis Package, 9. Mobile Application Part, 10. Modular Acoustic Processor, 11. MultiAssociative Processor. Abbreviation CAP is unique in interpretation, because it has even seventeen translation options: 1. Cable Access Point, 2. CAll Processor, 3. CAPacity, 4. CAPstan, 5. Carrierless Amplitude Phase, 6. Central Arbitration Point, 7. Channel Access Protocol, 8. Component Acceptance, 9. Computer-Aided Planning, 10. Computer-Aided Production, 11. Computer-Aided Programming, 12. Computer-Aided Publishing, 13. Console Action Processor, 14. Controlled Access Protection, 15. Centralized Automatic Testing, 16. Computer-Aided Testing, 17. Computerized Automatic Tester.

The problem of identifying those abbreviations that would simplify the process of mastering specialized foreign vocabulary is based on the selection of those variants that are consistent not only with the nouns being discussed above but also with some common spread verbs like to bite, to compare, did, to do, to eat, to fix, to move and made according to our previous article too 4 . Indicative factor is the existence of abbreviations, which are not only identical to the infinitive verb form but also to the Past Simple Tense forms.

The group to include some abbreviations being similar to common verbs in writing with unambiguous (one way) interpretation is represented in such abbreviations as BITE (Base Installation Test Equipment), COMPARE (Console for Optical Measurement and Precise Analysis of Radation from Electronics), EAT (Environment Acceptance), FIX (Fully Integrated Control System) and MOVE (Microsoft Overlay Virtual Environment).

4 Поліщук А.В, Якушко К.Г. Особливість омонімічності загальновживаних дієслів абревіатурам технічних термінів. Науковий вісник Національного університету біоресурсів $і$ природокористування Украӥни. Серія "Філологічні науки». 2018. Вип. 292. С. 217-221. 
The group to include some abbreviations being homonymous with common verbs with ambiguous interpretation.is represented by $M A D E$ being decoded in automation as Memory ADress Enable or Multichannel Analogto-Digital data Encoder.

The group to show some abbreviations being homonymous with common verbs with multispectral meaning is represented by a abbreviation $D I D$ as well as abbreviation $D O$. Abbreviation DID may be decoded in following six variants: 1. Data Input Display, 2. Destination IDentificator number, 3. Digital Information detection, 4. Digital Information Display, 5. Direct-In-Dialing, 6. Direct Inward Dial. Abbreviation $D O$ has eight meaning: 1. Data Organization, 2. Data Origination, 3. Data Output, 4. Deviating Oscillator, 5. Digital Output, 6. Dipole Orientation, 7. Disjunction Operation, 8. Drop Out.

The result of practical experience for future specialists in automation to involve professional vocabulary-abbreviations being corresponded with common words in order to revive interest in acquaintance with professional vocabulary was grounded in ability to represent free choice for every student to memorize some above-mentioned abbreviatins exampling LACE (Local Automatic Circuit), SOAP(Symbolic Optimal Assembly Program), FACT (Flexible Automatic Circuit Tester), CAR (Central Access Routing), CAP (Computer-Aided Planning), CAT (Centralized Automatic Testing), FIX (Fully Integrated Control System), DO (Digital Output), MAP (Manufacturing Automation Protocol), RAT (Receiver And Transmitter).

Continuing the description of students' work with abbreviations the practical experience for future specialists in automation to involve professional vocabulary in associative relations with emotional and psychomotor memories is also within our research interest. Here our goal is to describe the practical experience to fulfill psycholinguistic studies on the professionally oriented English lessons as well as to confirm conclusion that the assimilation of technical terms during the technical English practical classes may be deepened by transforming technical terms into some psycholinguistic images - thoughtform. Besides, we are aiming to agree that the foreign language professionally oriented technical broadcasting should be considered, first of all, as a moving-fluid creative phenomenon for the formation of speech products while human psychological activity either in the form of thinking units or in the form of linguistic images. These thoughts are consistent with the main provisions of the B. Gasparov's monograph "Language, Memory, Image" in which the importance of linguistic images observation is dealing with the person's spontaneous ability to respond to the fragments of language arising pictures, associations, schemes, reference abstracts, motor impulses, sensory sensations, written words in our minds ${ }^{5}$. The main attention is paid on gestures because they are related to the kinetic

5 Гаспаров Б.М. Язык, память, образ. Лингвистика языкового существования : монография. Москва.1996. 352 с. 
aspect of the figurative representations that the linguistic material. The dynamics of the gesture conveys the kinetic aspect of the image, which corresponds to this expression. We agree that only gesture itself helps the speaker and it is the best to feel the shaped projection of his expression to detect a similar figurative projection by interlocutor. In order to solve this task on English lessons for future specialists in automation within the National University of Life and Environmental Sciences of Ukraine technical terms introduction involved the elements of the terminological units transformation into thoughtform. While working with the future specialists in automation, the term bucket was always used in the form of a special box for mechanical actions of assembling and receiving the involved specialized terms to be in need for future specialist in automation for further work aiming to develop reference knowledge, to actualize associative links and to motivate usage of the explicit resources of psychomotor and emotional memory in the game form. Thus, it was proposed to continue some known statements using special terms. For example, Bacon's statement "Knowledge is a power" was continued as "...to order actuators and to set up automatic program", and a popular proverb "Measure it seven times but cut it once" due to the students' efforts was transformed into "Measure workshop's wires for automatic installation seven times but cut them only once". In such way in a form of game it was stimulation to know and to use such terms as automatic program, automatic installation, actuator, to set up, workshop, wires to measure, etc. Fixing of mysmetal data was also due to the assembly terms as puzzles in a live chain for fixing and memorizing these expressions as well as discussing humorous images about automatic concepts in pairs, dramatizing technical objects. Another time our future specialists in automation were offered to listen, to repeat, to translate the incendiary original song "Robot" and to be engaged into a team game "Guess the hidden words of a song on a professional subject observing a certain movement of another student: turning, applause, bouncing, squatting, stepping back and forward" and others paying attention such special words as robotics, sensing, switch, control, apparatus, regulator, software etc.

The result of practical experience for future specialists in automation to involve professional vocabulary in associative relations with emotional and psychomotor memories was grounded in ability to represent free choice for every student to memorize some above-mentioned terms like automatic installation, actuator, to order, to measure, robotics, sensing, control, apparatus, regulator or software.

Now it's turn to describe the practical experience for future specialists in automation to involve professional vocabulary being selected by common morpheme for adaptation to accept foreign terms by nesting method. 
Undoubtedly, the most relevant word-forming unit in the field of automation is morpheme aut- being analyzed in our previous article too ${ }^{6}$. There existence of forty attributive-nominative relations in the following constant terminological clichés was determined: 1) automatic actions, 2) automatic acceleration, 3) automatic aerosprayer, 4) automatic air supply to the burner, 5) automatic alarm, 6) automatic block, 7) automatic breaker, 8) automatic calculation, 9) automatic check, 10) automatic changeover, 11) automatic control, 12) automatic forecast data, 13) automatic hitch, 14) automatic hydraulic system, 15) automatic livestock waterer, 16) automatic indication, 17) automatic regulator, 18) automatic reset, 19) automatic sampler, 20) automatic release, 21) automatic meter prover, 22) automatic limiter, 23) automatic performance, automatic production control system, 24) automatic screw machine, 25) automatic search circuit, 26) automatic simulation model, 27) automatic systems design, 28) automatic systems development, 29) automatic traction equipment, 30) automatic transmission, 31) automatic up-to-date machinery exhibition, 32) automatic voltage regulator, 33) automatic tools, 34) automatical actions, 35) automation experience, 36) automation base, 37) automotive apparatus, 38) automotive function, 39) autoradiographic control, 40) autoronic sensor. After analyzing the modifications of the morpheme aut- from the represented sample we note the presence of adverbnoun relations in the following four constant terminological clichés: 1) automatically chosen instructions, 2) automatically controlled manipulator, 3) automatically controlled object, 4) automatically directly shared in the complete system.

Observing the modification of the morpheme aut- from a random sample of the above-mentioned text and vocabulary articles, let us consider the presence of nine adverb-noun relations as an attribute in the following constant terminological clichés: 1) autoloading machine, 2) automatic measuring tools, 3) automated blinds, 4) automated worker's cabin, 5) automatic selective soldering operations, 6) automatic selective dosing operations, 7) automatic metering devices, 8) automatic operating lever, 9) autotuning system.

Taking the example of modifying aut morphemes from an arbitrary sample of the above-mentioned modern text and vocabulary articles, we note the presence of fourteen nominative-noun relations as an attribute: 1) automata use, 2) autotimer use, 3) autotitrator use, 4) autotransductor application, 5) autotransformer application, 6) automation solutions, 7) autopilot couple, 8) autonavigator design, 9) autoscaler design, 10) autostabilizer design, 11) autostarter design, 12) auto-steer system

6 Якушко К.Г. Особливості лексичного складу та частотності вживання англійських термінологічних сполук $з$ морфемою aut. Молодий вчений. 2018. № 7(59). C. 154-158. 
application, 13) auto-steer systems included in many new tractors, 14) autosyn data.

After analyzing the modifications of the aut- morpheme from the sample above, let us note the presence of forty-six nominative noun relations by clarifying with as, of, from and for: 1)automatic control algorithm of multispectral camera parameters, 2) automatic control of biogas complex, 3) automatic control of energy flows, 4) automatic definition of robots details interchange, 5) automatic determination of amount of nitrogen in wheat leaves, 6) automatic determination of plant diseases, 7) automatic determination of nutritious solution concentration, 8) automatic determination of pests presence, 9) automatic drive of agricultural machinery, 10) automatic evaluation of absolute humidity, 11) automatic evaluation of biological objects state, 12) automatic evaluation of carbon dioxide $\mathrm{CO}_{2}$ concentration state, 13) automatic evaluation of plants nutrition state, 14) automatic evaluation of solar radiation state, 15) automatic means of production, 16) automatic purification of sewer waters, 17) automatic regulation of energy consumption in greenhouse, 18) automatic regulation of energy resources in cattle barn, 19) automatic regulation of energy resources in dairy plant, 20) automatic regulation of energy consumption in poultry farm, 21) automatic regulation of lighting regime, 22) automatic regulation of mushroom vegetation, 23) automatic regulation of soil moisture, 24) automatic regulation of temperature regime, 25) automatic regulation of wind speed, 26) automatic selection of dry matter, 27) automatic stabilization of cleaning process, 28) automatic stabilization of forage distribution process, 29) automatic stabilization ofpower feedback indicators, 30) automatic stabilization of power station operation, 31)automatic stabilization of pressure indicators, 32) automatic stabilization of store batteries feeding, 33) automatic stabilization of voltage indicators, 34) automatic stabilization of watering process, 35) automaton as the object to release peasant's labour, 36) autonomy of machines, 37) automatic systems for production of agricultural products, 38) automatic systems for proceeding of agricultural products, 39) automation as key component for success and profitability, 40) automation of control processes in agriculture, 41) automation of existing processes, 42) automatism of actions, 43) authentification of digital signals, 44) automated guided vehicles for factories, 45) automated tomography from multiple points, 46) automated gripping of loads.

Observing modifications of the morpheme aut- from an arbitrary sample of the above-mentioned modern text and vocabulary articles let us consider the existence of twenty-six attributive-procedural relations: 1) automatic aligning, 2) automatic balancing, 3) automatic billing, 4) automatic control circuit, 5) automatic control technology system, 6) automatic corn validity registration, 7) automatic couple, 8) automatic cycle, 9) automatic data exchange, 10) automatic drying, 11) automatic boosting, 12) automatic 
conveying, 13) automatic database concluding, 14) automatic error discovering, 15) automatic field weakening, 16) automatic multiple shot reclosing, 17) automatic packaging, 18) automatic phase comparison circuit, 19) automatic phytomonitoring of plants, 20) automatic plant raw materials processing, 21) automatic processing, 22) automatic processing of agricultural materials, 23) automatic reclosing, 24) automatic watering, $25)$ automatic wiring charging, 26) automatic systems testing. Taking the example of modifying morpheme aut- from a random selection of modern text and vocabulary articles, we note the presence of two verbal cliches: to automate agroindustrial complex, to automate the solution of any problem for which an algorithm exists.

As a result of the students' analys is of phrases with the morpheme auto-, the students' free choice was given to memorize and to apply in own speech ten the most common variants examplimg such ones as automatically chosen instructions, automatically controlled manipulator, automatically controlled object, automotive function, automatic simulation model, automatic measuring tools, automatic metering devices, automatic control algorithm of multispectral camera parameters, automatic definition of robots details interchange and automated gripping ofloads.

\section{Practical experience for future specialists in automation to involve professional vocabulary being selected by frequency of use in professional adapted foreign-language texts and by the most distinguished structural features using shortened list of the most used term compounds}

Our next stage is to distinguish practical experience for future specialists in automation to involve professional vocabulary being selected by frequency of use in professional adapted foreign-language texts. For terminological analysis of the text material, a language-adapted textual material from the field of automation was selected from the adequate textbook "English for the future specialists in agricultural automation"7. Students were in need to do step-by step linguinstic work having involved one part of text of one lesson.

The first part of it included such abstract as "The specialist in automation must know about APE (Automatic Processing Experiments), AR (Automation Research), AD (Automatic Design), ASP (Application Software Packages) etc. Also future engineer must know 13 subjects to be proposed by the Department of Automation: 1) Technological Process Simulation; 2) Automation System Design; 3) Computers and Computer Technology; 4) Theoretical Fundamentals of Automation; 5) Programming and Algorithmic Languages; 6) Computer Hardware and Computational Theory;

7 Якушко К.Г., Мірошник В.О., Дудник А.О., Лисенко В.П. English for the fut ure specialists in agricultural automation (Англійська мова для майбутніх фахівців 3 автоматизації АПК) : навчальний посібник. Київ. 2018. 351 с. 
7) Computer Graphics; 8) Automatic Control Theory; 9) Typical Production Facilities and Production Processes; 10) Identification and Process Simulation; 11) Real-Time Systems Programming; 12) Adaptive Control and Control Systems; 13) Computer-Aided Design (CAD) Systems For Technological Processes. Modern automata are able to release man in many instances from brain activity and, therefore, enable him to economize his forces for the creative processes. Automated surveillance real time mode in a particular environment presence of a number of sensors, responsible authority. Automation is the use of control systems for industrial machinery applying computer-aided technologies. The process of automation always includes installation of program, step-by-step acting, sensing, feedback with ACK and decision from the host computer with FTP. Automation is one of the areas of science and technology to use self-regulatory technical equipment, mathematical methods and control systems to relieve a person from participating in the process of acquisition, conversion, transmission and use of energy, materials or information, significantly reducing measure this participation or the complexity of the operations. Automated surveillance systems that are based on the fact that they are primarily designed for surveillance indoors or outdoors, in the presence of a number of sensors, the data from which the automated system can handle. The aim of surveillance is recording characteristics and trajectories of objects in a particular area, issuing a warning or notification to the responsible authority in the event of certain events. The control of autonomous robots involves a number of subtasks like understanding and modeling of the mechanism, kinematics, dynamics, reliable control of the actuators, closedloop control, generation of task -specific motion path planning, integ ration of sensors selection and interfacing of various types of sensors, coping and filtering of sensor noise, actuators application etc. Creation of flexible control policies has to deal with new situations too".

The second part of this textual material proclaimed that "Modern programming demands repetitive tasks, high speed, few sensing operations, high precision movement, pre-planned trajectories and no interaction with human. Modern robots have to be capable of achieving task without human input basing on sensor information. The modern robot must react dynamically according to the changes of its environment to achieve a task within intelligent environment. Robots need sensors to perceive the environment. Most of them use a set of different sensors. Different sensors serve different purposes. Information from sensors has to be integrated into the control of the robot. Proximity sensors are used to measure the distance or location of objects in the environment. This can then be used to determine the location of the robot. Infrared sensors determine the distance to an object by measuring the amount of infrared light the object reflects back to the robot. Ultrasonic sensors measure the time that an ultrasonic signal takes until it returns to the robot. Computer vision sensors provide robots 
with the capability to observe the environment passively. Stereo vision systems provide complete location information using triangulation. Robotic systems have to deal with sensor noise within intelligent environment too. Sensor readings are imprecise and unreliable. In a deliberative control architecture the robot firstly plans a solution for the task by reasoning about the outcome of its actions and then executes it. In a behavior-based control architecture the robot's actions are determined by a set of parallel, reactive behaviors which map sensory input and state to actions. Reactive, behaviorbased control combines relatively simple behaviors, each of which achieves a particular subtask, to achieve the overall task with instantaneous reaction. System does not depend on complete knowledge of the environment. Robotic systems need particular capabilities like autonomous control systems, simple and natural human-robot interface adaptive and learning capabilities as well as safety. Robots have to maintain safety during operation too. Suppose the instruction is: add the number in register B to the number in register A, send the sum to register $C$. Other valves will be needed for subtraction etc.".

The third part of the textual material dealt with the fact that "The computer should open the group of valves which transmit numbers over the adder. A computer is a machine with an intricate network of electronic circuits to operate switches. The main task of computer is to store, to calculate and to proceed data involving software, hardware, APD, BIOS and different circuit boards. The router may be applied to order initiate button or reset button on the monitor as well as browser screen. The part of the program to tell the computer what to do and the data to provide the concrete needed information to solve the problem are kept inside the computer in the place called RAM or ROM as memory arrays. Any problem is expressed in purely mathematical terms. It contains formulae, equations, calculations. But the problem is for the computer a thing beyond its understanding. The computer cannot handle formulae, equations or calculations. The computer does not know what man asks of it. The programmist is the connecting link between the computer and the problem it has to solve. The computer has to visualize and to subdivide any complex problem into a sequence of simple instructions that the computer could cope with. The computer has to realize all information transmission routes necessary for the execu tion of a certain sequence of operations".

The last fifth part of this textual material informed that "Every problem, even the simplest one, contains numerous instructions. Naturally, the more complicated is the problem, the longer is the list of instructions. The compilation of programmes is a very difficult job requiring high qualification. When the problem is compiled and laid into the computer, the latter sets to work. The purpose of the program is to provide instructions for the opening of a certain group of valves while keeping the others closed. The work of the computer is governed by the control block, the main element of the computer. This block exercises control over different parts of the 
computer, tells each part when it should go into action, what and how it should do. The control block concentrates in itself all the internal communications and "processes", all commands which control such a complex automation as the high-speed electronic computer. The operator switches on the computer and inserts a program containing a list of instructions that have to be performed in sequence in order to solve the program. The program in a computer is executed in sequence in cycles, step by step operation after operation. An instruction has been received by the control device. It immediately "opens" the appropriate group of valves and makes the computer carry out the instruction. To know about modelling of biological objects is to base upon the following image: According to the represented image agricultural enterprises are related to biotechnical objects, as they have two interrelated and interdependent components: biological (cattle, pigs, poultry, plants, mushrooms etc.) and technological which sells technology of maintenance and cultivation of biological components. This object relates to complex systems with some factors like a large number of factors that affect the performance of biological factors; complex nature of the relationship between the output parameters which include the performance of object and such input as temperature, humidity, light, feed composition and quality etc.; presence of "memory" in the biological factor; influence of environmental factors and weather on the biological object. Modelling of such systems cause many difficulties associated with considering number of factors that affect the various values, related to growth, productivity etc." "3.

The general term system of the proposed excerpt became the basis for the preparation of step-by-step block analysis cards in the following form with the emphasis on translation into the student's mother tongue (in our case, Ukrainian) being represented in table 2 .

Table 2

Automation text terms block analysis

\begin{tabular}{|c|c|}
\hline The title of block & The quantity of the used... in this block and examples \\
\hline $\begin{array}{l}\text { BLOCK 1 } \\
\text { (27 units) } \\
\text { "Automation as a } \\
\text { General Science" }\end{array}$ & 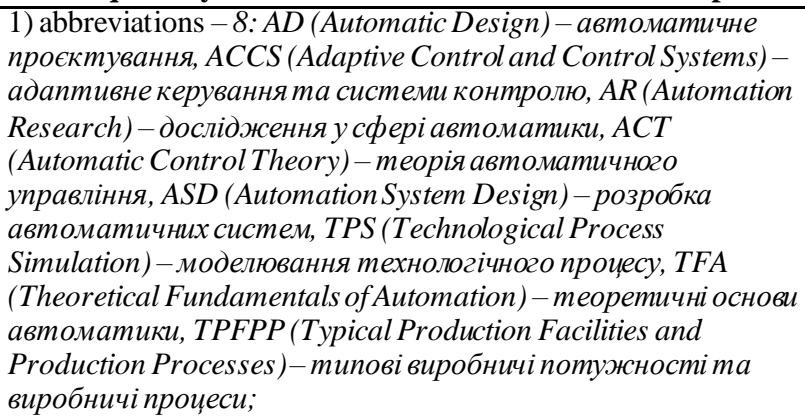 \\
\hline
\end{tabular}




\begin{tabular}{|c|c|}
\hline & 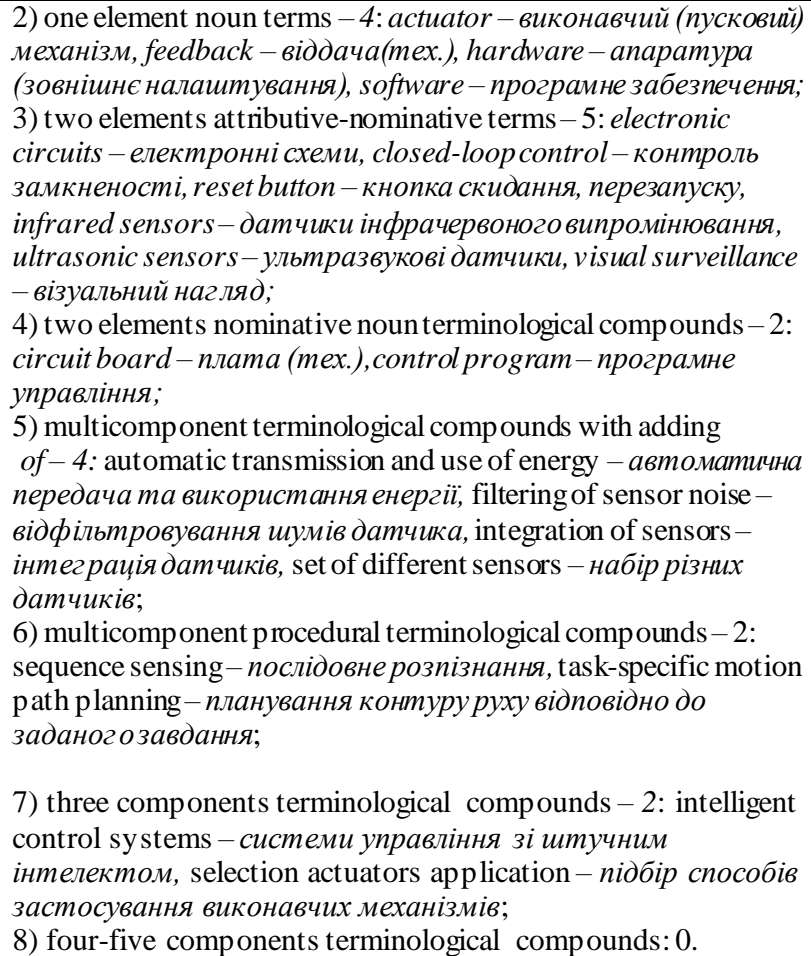 \\
\hline $\begin{array}{l}\text { BLOCK } 2 \\
\text { (9 units) } \\
\text { "Automation for } \\
\text { Agriculture" }\end{array}$ & 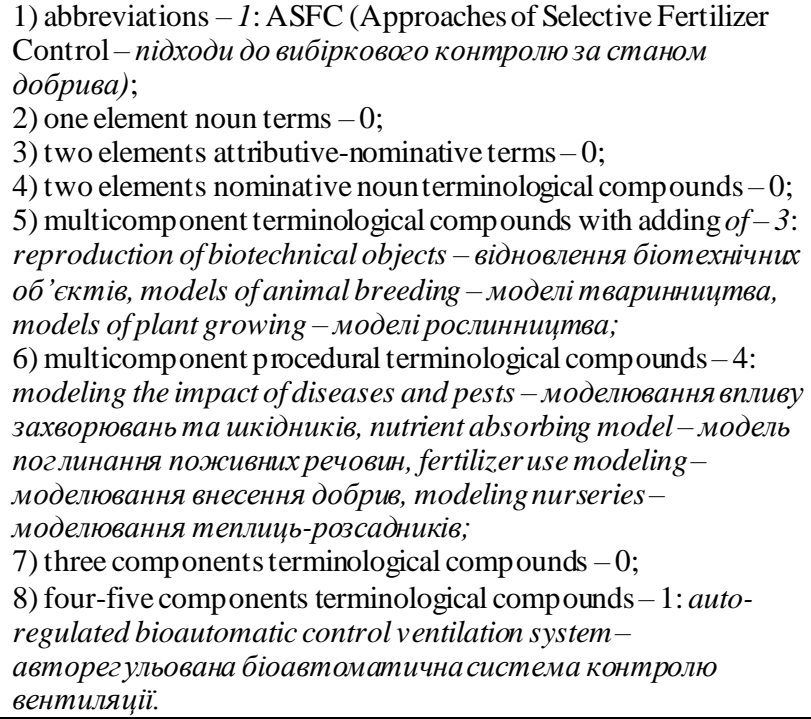 \\
\hline
\end{tabular}




\begin{tabular}{|c|c|}
\hline $\begin{array}{l}\text { BLOCK } 3 \text { (10 } \\
\text { units) } \\
\text { "Automation and } \\
\text { Robotics" }\end{array}$ & 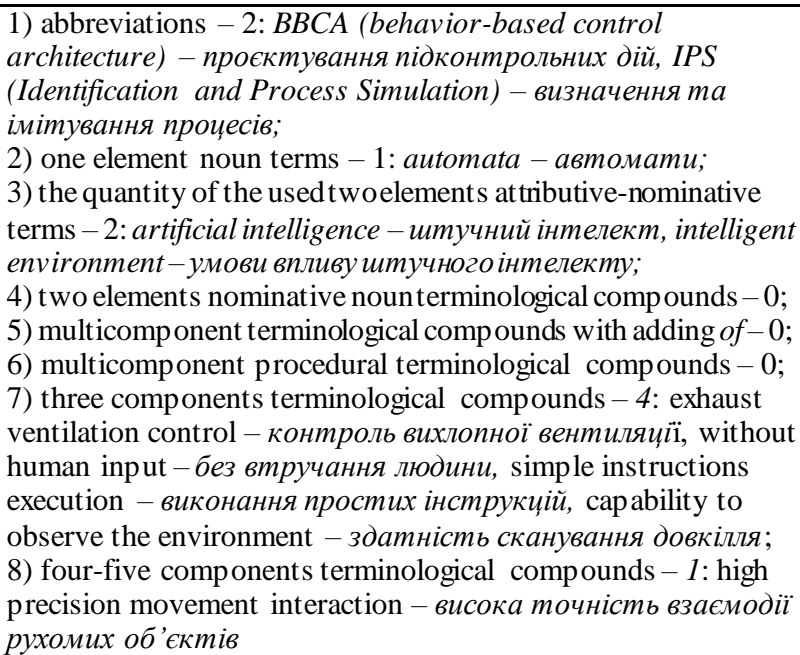 \\
\hline $\begin{array}{l}\text { BLOCK } 4 \text { (11 } \\
\text { units) } \\
\text { "Automation, } \\
\text { Computer aided } \\
\text { Technologies and } \\
\text { Mathematics" }\end{array}$ & 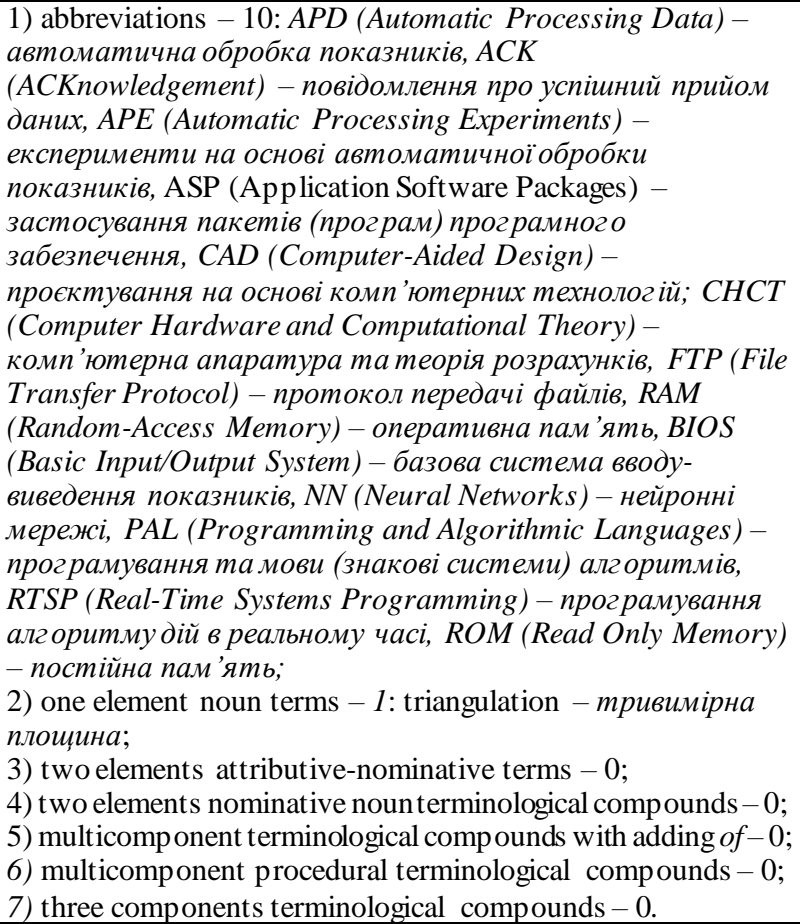 \\
\hline
\end{tabular}


The contextual analysis of the general text material within the sphere of automation provided the basis for the selection of the following thematic blocks of foreign language terms: "Automation as a General Science", "Automation for Agriculture", "Automation and Robotics", "Automation, Computer aided Technologies and Mathematics". The most content-rich in the textual material is the thematic block "Automation as a General Science", and content-rich in the textual material is the thematic block "Automation for Agriculture". The abbreviations of basic terms in automation are most fully presented in the thematic block "Automation, Computer aided Technologies and Mathematics" and the least fully presented - in block "Automation for Agriculture". One element noun terms are mostly used in block "Automation as a General Science" but they are rarely represented for other thematic blocks in the sphere of automation. Two elements attributive-nominative terms are mostly used in block "Automation as a General Science" and "Automation and Robotics" but they are not often used for others. Multicomponent terminological compounds with adding of are the most typical for such thematic blocks as "Automation as a General Science" and "Automation for Agriculture" and less typical for block "Automation, Computer aided Technologies and Mathematics" and block "Automation and Robotics". Multicomponent procedural terminological compounds are specific for block "Automation for Agriculture" as well as for block "Automation as a General Science" and are not specific for two others. Three components terminological compounds are mostly regarded to block "Automation and Robotics" as well as to block "Automation as a General Science". The clichés including four or five components are observed only for such thematic blocks as "Automation for Agriculture" or "Automation and Robotics".

Practical experience for future specialists in automation to involve professional vocabulary being selected by frequency of use in professional adapted foreign-language texts and by the most distinguished structural features was important. The result of the students' analysis of highfrequency word combinations and structural features of word combinations was students' free choice to memorize following fifteen most common variants: APD (Automatic Processing Data) - автоматична обробка показників, APE (Automatic Processing Experiments) - експерименти на основі автоматичної обробки показників, CAD (Coтputer-Aided Design) - проєктування на основі комп ютерних технологіü, high precision movement interaction - висока точність взаємодії рухомих об'єктів, artificial intelligence - штучний інтелект, IPS (Identification and Process Simulation) - визначення та імітування процесів), ВВСА (BehaviorBased Control Architecture) - проєктування підконтрольних дій, reproduction of biotechnical objects - відновлення біотехнічних об 'єктів, intelligent control systems - системи управління зі штучним інтелектом, selection actuators application - підбір способів застосування виконавчих 
механізмів, sequence sensing - послідовне розпізнання, task-specific motion path planning - планування контуру руху відповідно до заданого завдання, software - програмне забезпечення, hardware - anapaтура (зовнішне налаштування), AD (Automatic Design) - автоматичне проєктування.

Now our task is to distinguish the practical experience for future specialists in automation to involve vocabulary within a shortened list of the most used and the most suitable for professional use term compounds. A short list of the most commonly used and most suitable for professional use of terminology is advisable to include a series of results from each of the previous sections: automatically chosen instructions, automatically controlled manipulator, automatically controlled object, automotive function, automatic simulation model, automatic metering devices, automatic control algorithm of multispectral camera parameters, automatic definition of robots details interchange, automated gripping of loads, LACE (Local Automatic Circuit), SOAP (Symbolic Optimal Assembly Program), FACT (Flexible Automatic Circuit Tester), CAR (Central Access Routing), CAP (Computer-Aided Planning), CAT (Centralized Automatic Testing), FIX (Fully Integrated Control System), DO (Digital Output), MAP(Manufacturing Automation Protocol), RAT (Receiver And Transmitter), APD (Automatic Processing Data), APE (Automatic Processing Experiments), CAD (Computer-Aided Design), high precision movement interaction, artificial intelligence, IPS (Identification and Process Simulation), BBCA (Behavior-Based Control Architecture), reproduction of biotechnical objects, intelligent control systems, selection actuators application, sequence sensing, task-specific motion path planning, software, hardware, AD (Automatic Design).

The result of practical experience for future specialists in automation to involve vocabulary within a shortened list of the most used and the most suitable for professional use term compounds was in repeating all structures in student's chain and trying to apply all statements in students' own speech.

\section{Practical experience for future specialists in automation to involve professional vocabulary as the last review of residual knowledge and general results of theoretical grounds application}

Practical experience for future specialists in automation to involve professional vocabulary as the last review of residual knowledge is about to be the last stage in linguistic studies. The results may be represented in Table 3 to analyze the current review of residual students' professional vocabulary knowledge being dealt either with activity on each stage of linguistic work or with adequate category of vocabulary work to develop soft skills of engineers-technicians: 


\section{Current review of residual students' professional vocabulary knowledge in the sphere of automation}

\begin{tabular}{|c|c|c|}
\hline & Task & Student's answer \\
\hline 1 & $\begin{array}{l}\text { Write 5-10 variants of } \\
\text { professional vocabulary - } \\
\text { abbreviations being } \\
\text { corresponded with } \\
\text { common words in order } \\
\text { to revive interest in } \\
\text { acquaintance with } \\
\text { professional vocabulary }\end{array}$ & $\begin{array}{l}\text { 1. LACE ( Local Automatic Circuit). } \\
\text { 2 SOAP(Symbolic Optimal Assembly Program). } \\
\text { 3. FACT (Flexible Automatic Circuit Tester). } \\
\text { 4. CAR(Central Access Routing). 5. CAP } \\
\text { (Computer-Aided Planning). 6. CAT (Centralized } \\
\text { Automatic Testing). 7. FIX (Fully Integrated } \\
\text { Control System). 8. DO (Digital Output). 9. MAP } \\
\text { (Manufacturing Automation Protocol). 10. RAT } \\
\text { (Receiver And Transmitter). }\end{array}$ \\
\hline 2 & $\begin{array}{l}\text { Write 5-10 variants of } \\
\text { professional vocabulary } \\
\text { in associative relations } \\
\text { with emotional and } \\
\text { psychomotor memories }\end{array}$ & $\begin{array}{l}\text { 1. automatic installation, 2. actuator, 3. to order, } \\
\text { 4. to measure, 5. robotics, 6. sensing, 7. control, } \\
\text { 8. apparatus, 9. regulator, 10. software }\end{array}$ \\
\hline 3 & $\begin{array}{l}\text { Write 5-10 variants of } \\
\text { professional vocabulary } \\
\text { being selected by } \\
\text { common morpheme for } \\
\text { adaptation to accept } \\
\text { foreign terms by nesting } \\
\text { method }\end{array}$ & $\begin{array}{l}\text { 1. automatically chosen instructions. } \\
\text { 2. automatically controlled manipulator. } \\
\text { 3. automatically controlled object. 4. automotive } \\
\text { function, automatic simulation model. } \\
\text { 5. automatic measuring tools. } 6 . \text { automatic } \\
\text { metering devices. } 7 . \text { automatic control algorithm } \\
\text { of multispectral camera parameters. } 8 \text {. automatic } \\
\text { definition of robots details interchange. } \\
\text { 9. automated gripping of loads. }\end{array}$ \\
\hline 4 & $\begin{array}{l}\text { Write } 10-15 \text { variants of } \\
\text { professional vocabulary } \\
\text { being selected by } \\
\text { frequency of use in } \\
\text { professional adapted } \\
\text { foreign-language texts } \\
\text { and by the most } \\
\text { distinguished structural } \\
\text { features }\end{array}$ & 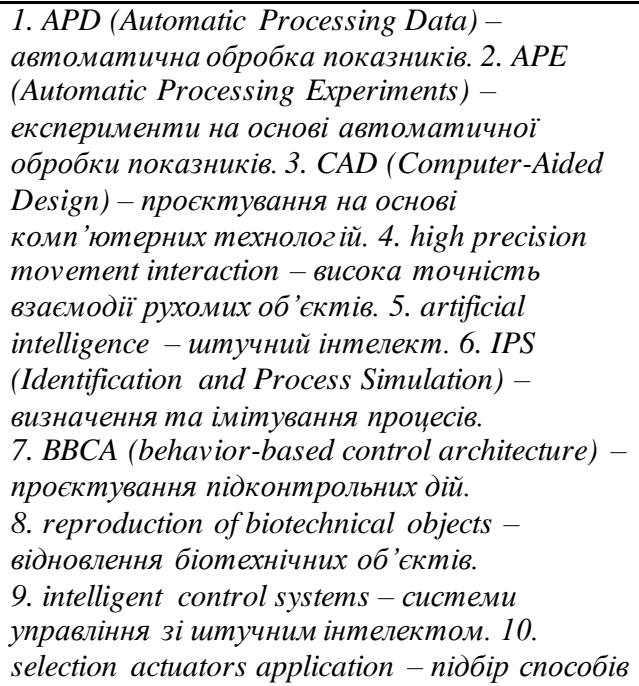 \\
\hline
\end{tabular}




\begin{tabular}{|c|c|c|}
\hline & & $\begin{array}{l}\text { застосування виконавчих механізмів. } \\
\text { 11. sequепсе sensing - послідовне розпізнання. } \\
\text { 12. task-specific motion path planning- } \\
\text { планування контуру руху відповідно до } \\
\text { заданого завдання, 13. software-програмне } \\
\text { забезпечення. 14. hardware-апаратура } \\
\text { (зовнішнє налаштування). } \\
\text { 15.АD (Аитотатіс Design)-автоматичне } \\
\text { проєктування }\end{array}$ \\
\hline 5 & $\begin{array}{l}\text { Write } 30-33 \text { variants of } \\
\text { vocabulary within a } \\
\text { shortened list of the most } \\
\text { used and the most } \\
\text { suitable for professional } \\
\text { use term compounds }\end{array}$ & 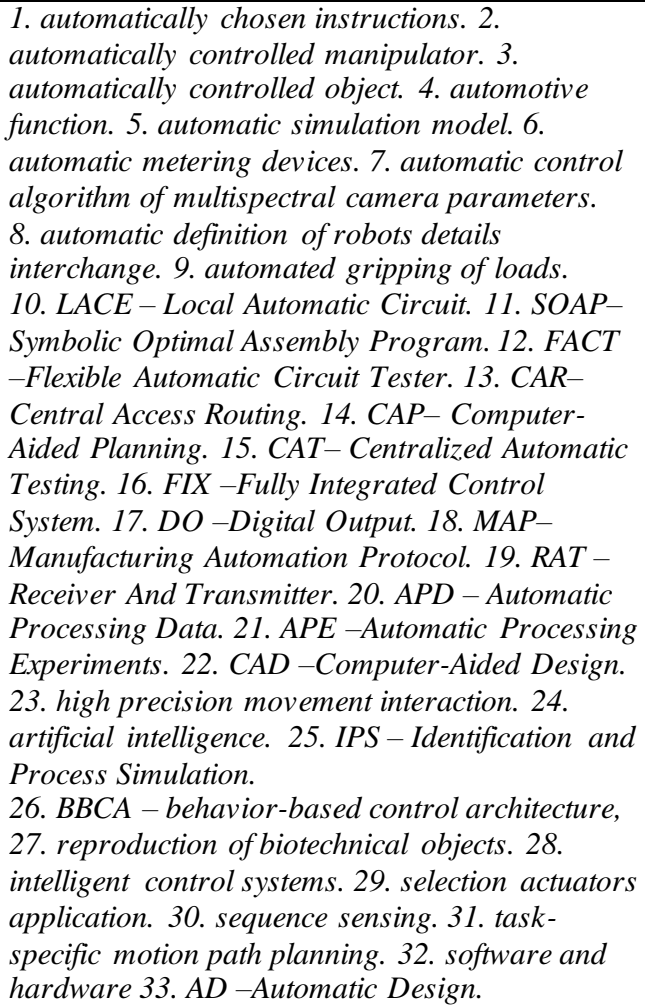 \\
\hline
\end{tabular}

After asking about residual professional foreign language knowledge 112 future specialists on automation within the National University of Life and Environmental of Ukraine were asked about the most suitable and important kinds of work while working with specialized vocabulary in the sphere of automation to develop students' foreign language communicative skills. The results may be represented in the following table 4: 
The student's decision about the importance and primarily usage of some kinds of activity with specialized activity in the sphere of automation

\begin{tabular}{|l|c|}
\hline \multicolumn{1}{|c|}{$\begin{array}{c}\text { The kind of activity with specialized } \\
\text { vocabulary in the spere of automatics }\end{array}$} & $\begin{array}{c}\text { Persentage (\%) of } \\
\text { importance and primarily } \\
\text { usage in student's own } \\
\text { speech }\end{array}$ \\
\hline $\begin{array}{l}\text { The work with professional vocabulary - } \\
\text { abbreviations being corresponded with common } \\
\text { words in order to revive interest in acquaintance } \\
\text { with professional vocabulary }\end{array}$ & 25 \\
\hline $\begin{array}{l}\text { The work with professional vocabulary in } \\
\text { associative relations with emotional and } \\
\text { psychomotor memories }\end{array}$ & 24 \\
\hline $\begin{array}{l}\text { The work with professional vocabulary being } \\
\text { selected by common morpheme for adaptation } \\
\text { to accept foreign terms by nesting method }\end{array}$ & \\
\hline $\begin{array}{l}\text { The work with professional vocabulary being } \\
\text { selected by frequency of use in professional } \\
\text { adapted foreign-language texts and by the most } \\
\text { distinguished structural features }\end{array}$ & 13 \\
\hline $\begin{array}{l}\text { The work with professional vocabulary within a } \\
\text { shortened list of the most used and the most } \\
\text { suitable for professional use term compounds }\end{array}$ & 11 \\
\hline
\end{tabular}

\section{CONCLUSIONS}

The article deals with the distinguishing and practical experience introduction of some categories of specialized vocabulary in the sphere of automation to develop several students' foreign language communicative skills. There are six main categories of linguistic studies for technical direction students basing upon professional vocabulary functional purpose to be found. According to the students choice it is actual to pay more attention and time on the work with professional vocabulary within a shortened list of the most used and the most suitable for professional use term compounds as well as on the work with professional vocabulary-abbreviations being corresponded with common words in order to revive interest in acquaintance with professional vocabulary or on professional vocabulary in associative relations with emotional and psychomotor memories.

\section{SUMMARY}

The article deals with the distinguishing and practical experience introduction of some categories of specialized vocabulary in the sphere of automation to develop several students' foreign language communicative 
skills. The main theoretical principles to determine the categories of professional vocabulary being involved into studying on the professionally oriented English language lessons may be based on their functional purpose. 6 adequate categories may be distinguished: 1) 1S: professional vocabulary as some abbreviations being corresponded with common words in order to revive technician's interest in linguistic work; 2) 2S: professional vocabulary in associative relations with emotional and psychomotor memories; 3) 3S: professional vocabulary being selected by common morpheme for adaptation to accept foreign terms by nesting method; 4) 4S: professional vocabulary being selected by frequency of use in professional adapted foreign-language texts and by the most distinguished structural features; 5) $5 \mathrm{~S}$ : professional $1 \mathrm{~S}, 2 \mathrm{~S}, 3 \mathrm{~S}, 4 \mathrm{~S}$ vocabulary within a shortened list of the most used and the most suitable for professional use term compounds; 6) $6 \mathrm{~S}$ : professional vocabulary as the current review of residual linguistic knowledge. Linguistic studies on the of professional foreign language lessons attract the attention of technicians - future specialists in automation mostly as the activity within a shortened list of the most used and the most suitable for professional use term compounds as well as on the work with professional vocabulary-abbreviations being corresponded with common words in order to revive interest in acquaintance with professional vocabulary or on professional vocabulary in associative relations with emotional and psychomotor memories. The less efficient activity is work with professional vocabulary being selected by common morpheme for adaptation to accept foreign terms by nesting method and professional vocabulary being selected by frequency of use in professional adapted foreign-language texts and by the most distinguished structural features. The adequate linguistic studies with professional vocabulary studies must be further applied and the results must be compared basing upon next year students' conclusion within the National University of Life and Environmental Sciences of Ukraine or within another higher educational establishment to train specialists in the area of automation.

\section{REFERENCES}

1. Liudmyla V. Berezova, Svitlana V. Mudra, Kateryna H. Yakushko. The Effect of Webquests of the Writing and Reading Performance of University students. Information Technologies and Learning Tools. 2018. Vol. 64, No. 2. C. 110-118. DOI: https://doi.org/10.33407/itlt.v64i2.

2. Гаспаров Б.М. Язык, память, образ. Лингвистика языкового существования : монография. Москва.1996. 352 с.

3. Поліщук А.В, Якушко К.Г. Особливість омонімічності загальновживаних дієслів абревіатурам технічних термінів. Науковий 
вісник Національного університету біоресурсів і природокористування Украӥни. Серія «Філологічні науки». 2018. Вип. 292. С. 217-221.

4. Якушко К.Г. Особливості лексичного складу та частотності вживання англійських термінологічних сполук 3 морфемою aut. Молодий вчений. 2018. № 7(59). С. 154-158.

5. Якушко К.Г. Педагогічні умови формування професійно орієнтованого іншомовного спілкування у студентів технічних спеціальностей аграрних університетів : монографія. / за наук. ред. проф. Л.О. Калмикової. Київ. 2017. 244 с.

6. Якушко К.Г., Мірошник В.О., Дудник А.О., Лисенко В.П. English for the future specialists in agricultural automation (Англійська мова для майбутніх фахівців 3 автоматизації АПК) : навчальний посібник. Київ. 2018. $351 \mathrm{c}$.

7. Якушко К.Г., Поліщук А.В. Особливості співзвучності загальновживаних іменників 3 абревіатурами технічних термінів. Науковий вісник Національного університету біоресурсів і природокористування Украӥни. Серія «Філологічні науки». 2018. Вип. 292. С. 222-227.

\section{Information about the author:} Yakushko K. H.,

Candidate of Pedagogical Sciences, Senior Lecturer of the Department of English for Technical and

Agrobilogical Specialties of Ukraine National University of Life and Environmental Sciences of Ukraine 5, Heroiv Oborony str., Kyiv, 03041, Ukraine 